\title{
MicroRNA-504 modulates osteosarcoma cell chemoresistance to cisplatin by targeting p53
}

\author{
XIN CHEN ${ }^{1,2 *}$, CHEN LV $^{2 *}$, XIONGBAI ZHU², WENJUN LIN ${ }^{2}$, LU WANG $^{2}$, \\ ZHENGXIANG HUANG ${ }^{2}$, SHENGWU YANG ${ }^{2}$ and JUNYING SUN ${ }^{1}$
}

${ }^{1}$ Department of Orthopaedics and Traumatology, The First Affiliated Hospital of Soochow University, Suzhou, Jiangsu 215000;

${ }^{2}$ Department of Orthopaedics, The First Affiliated Hospital of Wenzhou Medical University,

Wenzhou, Zhejiang 325000, P.R. China

Received December 3, 2017; Accepted September 13, 2018

DOI: $10.3892 / 01.2018 .9749$

\begin{abstract}
Chemoresistance implicates the therapeutic value of cisplatin and remains a primary obstacle to its clinical use. MicroRNAs (miRs) negatively modulate the expression of their target genes and are associated with the occurrence and progression of various types of tumor. The abnormal expression of miR-504 has been reported in certain types of human tumor and has been associated with tumor prognosis. However, the association between miR-504 and cisplatin in human osteosarcoma remains unclear. The present study therefore aimed to assess the in vitro effects and possible mechanism of miR-504 in cell proliferation, apoptosis and cisplatin resistance in MG63 osteosarcoma cells. The results demonstrated that miR-504 was overexpressed in osteosarcoma tissues and cells. This overexpression also induced cell proliferation, as determined by MTT and EdU staining assays. Furthermore, miR-504 suppressed cisplatin-induced apoptosis, which was demonstrated via MTT, cell morphology analysis and flow cytometry. Cisplatin-induced $\mathrm{G}_{1}$ arrest was also suppressed, which was determined by flow cytometry. The potential target genes of miR-504 were predicted using bioinformatics. p53 was confirmed to be a direct target of miR-504 using a luciferase reporter assay and western blot analysis revealed that miR-504 negatively regulated p53 expression at a molecular level. These results indicate that miR-504 contributes to cisplatin resistance in MG63 osteosarcoma cells by suppressing p53. miR-504 may therefore be a potential biomarker for cisplatin resistance in patients with osteosarcoma.
\end{abstract}

Correspondence to: Dr Junying Sun, Department of Orthopaedics and Traumatology, The First Affiliated Hospital of Soochow University, 188 Shizi Street, Gusu, Suzhou, Jiangsu 215000, P.R. China E-mail: sunjunying392@163.com

*Contributed equally

Key words: apoptosis, cisplatin, proliferation, microRNA-504, osteosarcoma, p53

\section{Introduction}

Osteosarcoma originates from mesenchymal cells and is the most common primary malignant bone tumor affecting children and adolescents $(1,2)$, accounting for $\sim 5 \%$ of all pediatric tumors $(3,4)$. The 5 -year survival rate $(60-70 \%)$ of patients with osteosarcoma has significantly improved in their 10-year follow-up, due to the implementation of combined treatment with surgery and multi-agent chemotherapy $(5,6)$. Cisplatin is the most commonly used antitumor drug, but its therapeutic value is uncertain due to chemoresistance (7). Therefore, further investigation on how to reduce cisplatin resistance and improve the therapeutic effect of cisplatin in osteosarcoma is required $(8,9)$.

MicroRNAs (miRNAs, miRs) are short ( 22 nucleotides) endogenous, non-coding, single-stranded RNAs that post-transcriptionally regulate the expression of their target genes (10). miRNAs directly affect the stability of their target mRNA or inhibit its translation by binding to its 3 'untranslated region $\left(3^{\prime}\right.$-UTR) $(11,12)$. miRNAs are involved in a variety of biological processes, including cell survival, differentiation, proliferation, apoptosis, autophagy, motility and metabolism $(13,14)$. Abnormal miRNA expression may exhibit tumor suppressor or oncogenic effects, which influence the occurrence and progression of malignant tumors $(15,16)$. Several miRNAs have been confirmed to be involved in osteosarcoma chemoresistance. Meng et al (17) revealed that miR-140-5p regulated autophagy-mediated osteosarcoma chemoresistance by targeting high mobility group nucleosome binding domain 5. Furthermore, Vanas et al (18) demonstrated that miR-21 facilitated osteosarcoma cell proliferation and decreased cisplatin sensitivity by targeting sprouty RTK signaling antagonist 2. Additionally, Liu et al (19) determined that miR-200c suppressed cell proliferation and enhanced cisplatin sensitivity in osteosarcoma cells by targeting serine/threonine kinase 2 . These studies provide evidence for the use of certain miRNAs as effective predictive markers for cisplatin resistance in osteosarcoma.

p53 was the first tumor suppressor gene to be identified and is mutated in $~ 50 \%$ of osteosarcomas (20). The absence of normal $\mathrm{p} 53$ function serves an important role in tumor occurrence and progression, as $\mathrm{p} 53$ protein induces cell cycle arrest, 
apoptosis or the senescence of damaged or mutant cells to prevent their proliferation, which may otherwise promote tumor occurrence and progression (21-23). Zhao et al (24) demonstrated that p53 overexpression increased chemosensitivity in multidrug-resistant osteosarcoma cell lines and $\mathrm{Wu}$ et al (25) revealed that $\mathrm{p} 53$ expression was a useful prognostic biomarker for the prediction of survival in patients with osteosarcoma. Previous studies have demonstrated that specific miRNAs are involved in an additional p53-associated mechanism of osteosarcoma suppression (26,27). He et al (28) determined that miR-34 suppressed osteosarcoma cell proliferation and invasion by targeting p53, whilst Zhang et al (29) determined that miR-29 induced osteosarcoma cell apoptosis via the activation of $\mathrm{p} 53$.

miR-504 has been associated with several types of malignant tumor, particularly in association with cell proliferation and apoptosis, with a previous study demonstrating that miR-504 is overexpressed in osteosarcoma (30). However, to the best of our knowledge, the specific role and mechanism of miR-504 in modulating cisplatin resistance in osteosarcoma cells is yet to be elucidated. The current study therefore aimed to clarify the role and mechanism of miR-504 in the modulation of cisplatin resistance in human osteosarcoma cells. The results of the present study verified that miR-504 promoted cell proliferation and contributed to cisplatin-induced apoptosis and cell cycle arrest in MG63 osteosarcoma cells, by targeting p53. These results indicate that miR-504 may be a novel target for the reduction of cisplatin resistance.

\section{Materials and methods}

Tissue samples, cell culture, lentivirus infection and cell treatment. Osteosarcoma tissues and adjacent normal tissues ( $\mathrm{n}=10$ pairs; $2-5 \mathrm{~cm}$ apart) were collected between September 2016 and May 2017 during routine therapeutic surgery at the Department of Orthopaedics at the First Affiliated Hospital of Wenzhou Medical University (Wenzhou, China). The human osteosarcoma tissues and pair-matched adjacent normal tissues were subsequently used to compare the expression of miR-504 by reverse transcription-quantitative polymerase chain reaction (RT-qPCR). The role of miR-504 in osteosarcoma progression was subsequently analyzed in vitro by using MG63 cells. A total of 10 patients (range, 12-22 years of age), 4 male and 6 female, participated in the present study. Inclusion criteria were as follows: Patients with a pathological diagnosis of osteosarcoma, original site of osteosarcoma was the long bone of limbs, patients receiving surgical treatment and follow-up time $\geq 12$ months. The exclusion criteria were as follows: Pathological diagnosis of non-osteosarcoma, original site of osteosarcoma was not the long bone of limbs, patient did not receive surgical treatment and follow-up time was $<12$ months.) Immediately following surgery, tumor tissues were stored at $-80^{\circ} \mathrm{C}$ until further use.

The human osteosarcoma cell line MG63 and human fetal osteoblastic cell line hFOB1.19 were obtained from ZQXZ Biotech co.,Ltd. (Shanghai, China) and cultured in high-glucose Dulbecco's Modified Eagle's medium (DMEM-HG) and DMEM Nutrient Mixture F-12 medium (DMEM-F12; both Gibco; Thermo Fisher Scientific, Inc., Waltham, MA, USA), respectively. MG63 and hFOB1.19 cells were cultured for $\sim 36 \mathrm{~h}$ at $37^{\circ} \mathrm{C}$ in a humidified incubator supplemented with $5 \% \mathrm{CO}_{2}$ and harvested using $0.25 \%$ trypsin/0.02\% EDTA solution (Gibco; Thermo Fisher Scientific, Inc.) once the adherent cells had reached a confluence of 80\%. pGCMV-hsa-miR-504-up (miR-504) and negative control (NC or miR-NC; green fluorescent protein-labeled empty vector) lentiviruses were provided by Shanghai GeneChem Co., Ltd. (Shanghai, China). Osteosarcoma cells were then seeded in 6-well plates (4x10 $/$ well, $200 \mu \mathrm{l} /$ well), grown to a confluence of $30-50 \%$ $\left(\sim 5 \times 10^{4} /\right.$ well $)$ and then infected with miR-504 or the miR-NC lentivirus, where each sample contained $1 \mu \mathrm{l}$ of polybrene $(5 \mu \mathrm{g} / \mathrm{ml})$ and $25 \mu \mathrm{l}$ of lentivirus $\left(1 \times 10^{8}\right.$ Tube $\left./ \mathrm{ml}\right)$ at a final multiplicity of infection of 50 (based on a preliminary study) for $96 \mathrm{~h}(31,32)$. The efficiency of miR-504 was detected using a RT-qPCR assay as subsequently performed. The osteosarcoma cells were then divided into three groups: A normal group cultured without additional handling, an miR-NC group transfected with the NC lentivirus and an miR-504 group transfected with the miR-504 lentivirus.

RNA isolation and RT-qPCR. Total RNA was extracted from the two cells, MG63 and hFOB1.19 using TRIzol (Invitrogen; Thermo Fisher Scientific, Inc.). mRNA was reverse transcribed at $25^{\circ} \mathrm{C}$ for $30 \mathrm{~min}, 42^{\circ} \mathrm{C}$ for $30 \mathrm{~min}$ and $85^{\circ} \mathrm{C}$ for 5 min. RT-qPCR was performed using a Hairpin-it ${ }^{\mathrm{TM}}$ miRNA RT-PCR Quantification kit (Shanghai GenePharma Co., Ltd., shanghai, China), according to the manufacturer's protocols. The kit of RT contains 5x MMLV RT buffer, dNTP (10 mM), miR-RT primers $(1 \mu \mathrm{M})$, RNasin $(40 \mathrm{U} / \mu \mathrm{l})$, MMLV Reverse Transcriptase $(200 \mathrm{U} / \mu \mathrm{l})$, and $\mathrm{RNase}$ Free $\mathrm{H}_{2} \mathrm{O}$. The kit of qPCR includes 2XReal-time PCR Master Mix, miR-504 specific Primer set $(10 \mu \mathrm{M})$, miR-504 specific Probe $(10 \mu \mathrm{M})$, Taq DNA polymerase $(5 \mathrm{U} / \mu \mathrm{l})$ and sterilized $\mathrm{H}_{2} \mathrm{O}$. Thermocycling conditions of miR-504 qPCR were as follows: 1 cycle at $95^{\circ} \mathrm{C}$ for $3 \mathrm{~min}$ (pre-degeneration), 40 cycles at $95^{\circ} \mathrm{C}$ for $12 \mathrm{sec}$, and fluorescent signal acquisition at $62^{\circ} \mathrm{C}$ for $40 \mathrm{sec}$. miR-504 and U6 small nuclear (sn)RNA PCR reverse primers were synthesized by Shanghai GenePharma Co., Ltd. The forward and reverse primer sequences were as follows: miR-504 forward, 5'-CCA GCAAGACCCTGGTCTG-3' and reverse, 5'-CAGAGCAGG GTCCGAGGTA-3'; U6 snRNA forward, 5'-ATTGGAACG ATACAGAGAAGATT-3' and reverse, 5'-GTTTAAGCACTT CGCAAGG-3'. miR-504 expression data were normalized to U6 snRNA. Specific products were detected and analyzed using a Roche LightCycler 480 Detection System (Roche Diagnostics, Basel, Switzerland). The $2^{-\Delta \Delta \mathrm{Cq}}$ method (33) was used to calculate the relative expression of miR-504.

Cell proliferation assay. Cell proliferation was evaluated via an MTT assay. MG63 cells (4x10\%/well) infected with miR-504 and miR-NC were seeded in 96-well plates and cell proliferation was measured at $6,12,24,48,72$ and 96 h. $150 \mu 1$ of MTT was added to each well and the plate was incubated at $37^{\circ} \mathrm{C}$ for a further $4 \mathrm{~h}$. Dimethyl sulfoxide was then added to dissolve the sediment. Absorbance was measured at $490 \mathrm{~nm}$ using a Spectra Max Plus 384 microplate reader (Molecular Devices LLC, Sunnyvale, CA, USA). Cell proliferation was also detected via an EdU assay, using an EdU cell proliferation detection kit (Nanjing KeyGen Biotech Co., Ltd., Nanjing, China). The cells ( $4 \times 10^{4} /$ well) were seeded in 6-well plates and 
cultured at $37^{\circ} \mathrm{C}$ for $48 \mathrm{~h}$, and then incubated with DMEM containing EdU (Nanjing KeyGen Biotech Co., Ltd.). They were subsequently fixed in $4 \%$ paraformaldehyde at $4{ }^{\circ} \mathrm{C}$ for 30 min, washed twice with PBS, reacted with Apollo 643 and dissolved in Apollo reaction buffer (Nanjing KeyGen Biotech Co., Ltd., Nanjing, China). The cells were subsequently stained with DAPI at $37^{\circ} \mathrm{C}$ for $3 \mathrm{~min}$ and observed under an inverted phase contrast fluorescence microscope (magnification, $\mathrm{x} 400$; Carl Zeiss AG, Oberkochen, Germany). Cells stained red were considered EdU-positive.

Cell viability assay. Cell viability was also evaluated via an MTT assay. MG63 cells from the normal group (4x10\%/well) were seeded in 96-well plates and pretreated with different concentrations $(0,2.5,5,7.5,10,12.5,15,17.5$ and $20 \mu \mathrm{g} / \mathrm{ml})$ of cisplatin (Qilu Pharmaceutical Co., Ltd., Jinan, China) for 24 and $48 \mathrm{~h}$. MTT solution was then added to each well and the plate was incubated at $37^{\circ} \mathrm{C}$ for $4 \mathrm{~h}$. Dimethyl sulfoxide was added to dissolve the sediment. Absorbance was measured at $490 \mathrm{~nm}$ using a microplate reader. An appropriate concentration of cisplatin $\left(\sim 10 \mu \mathrm{g} / \mathrm{ml} ; \mathrm{IC}_{50}\right.$, half maximal inhibitory concentration) was then selected to treat the different groups for 24,48 and $72 \mathrm{~h}$, respectively, using the aforementioned method.

Cell apoptosis detection. Cell apoptosis was assessed using an Annexin V-APC/7 aminoactinomycin D (7AAD) apoptosis detection kit (Nanjing KeyGen Biotech Co., Ltd.). MG63 cells were harvested, washed twice with PBS, resuspended in binding buffer contained in the aforementioned kit, stained with Annexin V-APC and 7AAD () at $37^{\circ} \mathrm{C}$ for $10 \mathrm{~min}$, and analyzed using a flow cytometer FACSCalibur system and CellQuest 5.1 software (BD Biosciences, San Jose, CA, USA).

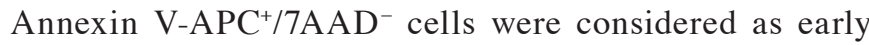
apoptotic cells, while Annexin $\mathrm{V}-\mathrm{APC}^{+} / 7 \mathrm{AAD}^{+}$cells were considered as late apoptotic or necrotic cells.

Morphology of apoptotic cells. Apoptotic MG63 cell morphology was observed directly using an inverted phase contrast (fluorescence; magnification, x100 and x400). Cells $\left(6 \times 10^{4} /\right.$ well) were cultured in 6 - and 24 -well plates at $37^{\circ} \mathrm{C}$ for $24 \mathrm{~h}$, and apoptosis was induced by cisplatin $(10 \mu \mathrm{g} / \mathrm{ml})$. Cells in the 6-well plate were observed directly under an inverted phase contrast microscope (magnification, $\mathrm{x} 100$ ). Cells in 24-well plate were washed twice with PBS, fixed in $4 \%$ paraformaldehyde at $4^{\circ} \mathrm{C}$ for $30 \mathrm{~min}$, stained with Hoechst 33258 staining solution (Beyotime Institute of Biotechnology, Shanghai, China) at $37^{\circ} \mathrm{C}$ for $10 \mathrm{~min}$ and washed twice with PBS. A total of $20 \mu \mathrm{l}$ of Anti-fading solution (Beyotime Institute of Biotechnology) was then dropped onto the cells and they were imaged under an inverted phase contrast fluorescence microscope (magnification, $\mathrm{x} 400$ ).

Cell cycle analysis. The cell cycle was analyzed using a DNA content quantitation (cell cycle) detection kit (Nanjing KeyGen Biotech Co., Ltd.). MG63 cells were harvested, washed twice with PBS and fixed in $70 \%$ ethanol overnight at $4^{\circ} \mathrm{C}$. The following day, the cells were centrifuged $\left(800 \mathrm{x} \mathrm{g}, 4^{\circ} \mathrm{C}, 5 \mathrm{~min}\right)$, washed twice with $\mathrm{PBS}$, stained with propidium iodide and RNase A (Nanjing KeyGen Biotech Co., Ltd.), and analyzed using a flow cytometer FACSCalibur system and CellQuest 5.1 software (BD Biosciences).

Target mRNA gene prediction. The TargetScanHuman database (Agarwal V et al.; http://www.targetScan.org; TargetScanHuman Release 7.1 software) (34) was used to predict the potential target gene of miR-504.

Dual luciferase reporter assay. Briefly, 293 cells (1x10 $/$ well) (35) were seeded in 96-well plates and luciferase activities were measured using a dual luciferase reporter assay, the Firefly and Renilla luciferase assay kit, (Biotium, Inc., Freemont, CA, USA), according to the manufacturer's protocols (36). Cells were co-transfected with pGL3-miR-504 (miR-NC)-3'-UTR-wild type (wt)-p53 or pGL3-miR-504 (miR-NC)-3'-UTR-mutant (mut)-p53 plasmid (Promega Coorporation, Madison, WI, USA) using Lipofectamine ${ }^{\circledR} 2000$. Following transfection for 48 h, Firefly and Renilla luciferase activities were measured using a dual luciferase reporter assay system (Biotium, Inc., Freemont, CA, USA). Renilla luciferase activity was used as an internal control for the evaluation of transfection efficiency.

Western blot analysis. Protein expression was evaluated via western blotting. MG63 cells were lysed in radioimmunoprecipitation assay lysis buffer (Beyotime Institute of Biotechnology). Protein concentrations were measured by bincinchoninic acid assay (CW Biotechnology, Beijing, China). Total protein $(30 \mu \mathrm{g})$ was separated using sodium dodecyl sulfate-polyacrylamide gel electrophoresis on a $12 \%$ running gel and 5\% stacking gel, and then transferred to polyvinylidene fluoride membranes $(0.45 \mu \mathrm{m}$; Merck KGaA, Darmstadt, Germany). Membranes were subsequently blocked with $5 \%$ non-fat milk in Tris-buffered saline with Tween-20 (TBS-T), containing 5\% bovine serum albumin (BD Biosciences) at $4^{\circ} \mathrm{C}$ overnight and incubated with the following primary antibodies: Rabbit antibodies against p53 (dilution, 1:1,000; cat. no. 2527); Bcl-2-associated X (Bax; dilution, 1:1,000; cat. no. 5023); B cell lymphoma-2 (Bcl-2; dilution, 1:1,000; cat. no. 4223); caspase-3 (dilution, 1:1,000; cat. no. 9665); p21 (dilution, 1:1,000; cat. no. 2947); cyclin D1 (dilution, 1:1,000; cat. no. 2978) and GAPDH (dilution, 1:1,000; cat. no. 5174); mouse antibody to $\beta$-actin (dilution, 1:1,000; cat. no. 3700) all purchased from Cell Signaling Technology, Inc., (Danvers, MA, USA). They were subsequently washed three times with TBS-T and incubated with horseradish peroxidase-conjugated secondary antibodies (goat-anti-rabbit; dilution, 1:5,000; cat. no. CW0234; and goat-anti-mouse; dilution, 1:5,000; cat. no. CW0108); CW Biotechnology) in TBS-T at room temperature for $2 \mathrm{~h}$. All proteins were visualized using an enhanced chemiluminescence system (Thermo Fisher Scientific, Inc.).

Statistical analysis. Significant differences between groups were evaluated using one-way analysis of variance, followed by Student-Newman-Keuls test. All of the statistical analyses were carried out using SPSS 18.0 software (SPSS, Inc., Chicago, IL, USA). Graphs were created using GraphPad Prism 6 software (GraphPad Software, Inc., La Jolla, CA, USA). All data were presented as mean \pm standard error of 
the mean and three independent experiments were analyzed. $\mathrm{P}<0.05$ was considered to indicate a statistically significant difference.

\section{Results}

miR-504 expression is increased in human osteosarcomatissues and MG63 osteosarcoma cells. Aberrant miR-504 expression has been reported in certain types of human tumor (20). The current study assessed miR-504 expression in human osteosarcoma tissues and pair-matched adjacent normal tissues (10 pairs) using RT-qPCR. miR-504 expression was significantly increased in osteosarcoma tissues compared with normal adjacent tissues $(\mathrm{P}<0.05$; Fig. 1A). miR-504 expression was also determined in MG63 osteosarcoma cells using RT-qPCR, with hFOB1.19 osteoblastic cells as controls. It was demonstrated that miR-504 expression was significantly increased in MG63 cells compared with hFOB1.19 cells ( $\mathrm{P}<0.05$; Fig. 1B). These results indicated that miR-504 expression levels were increased in human osteosarcoma tissues and osteosarcoma cells.

miR-504 lentivirus successfully infects MG63 cells. To clarify the potential role of miR-504 in osteosarcoma progression, miR-504 was overexpressed in MG63 cells via infection with a miR-504 lentivirus. The results demonstrated that miR-504 expression was 7.75 \pm 1.29 -fold higher in the infected cells compared with the normal cells, as determined by RT-qPCR $(\mathrm{P}<0.05$; Fig. 2A). There was no significant difference in miR-504 expression between the miR-NC and normal group. These results indicated that the miR-504 lentivirus was successfully infected into MG63 cells.

miR-504 promotes cell proliferation. The role of miR-504 in MG63 cell proliferation was assessed via an MTT assay. Cell proliferation was compared between the three groups from 6 to $96 \mathrm{~h}$. The results demonstrated that miR-504 significantly increased MG63 cell proliferation (from $48 \mathrm{~h}$ ) compared with the normal group $(\mathrm{P}<0.05$; Fig. 2B). The greatest increase in proliferation rate was determined at $96 \mathrm{~h}$ in the miR-504 group, when compared with the normal group (1.61 \pm 0.18$)$. However, no significant differences were identified between the miR-NC and the normal group (Fig. 2B). These results were confirmed via an EdU assay, which demonstrated that EdU-incorporation was significantly increased in the miR-504 group compared with the normal group $(\mathrm{P}<0.05$; Fig. $2 \mathrm{C})$. However, there were no significant differences between the miR-NC and normal group. These results confirmed that miR-504 promotes MG63 cell proliferation.

Cisplatin induces cell apoptosis and suppresses miR-504 expression in MG63 cells. While Cisplatin has been identified as an effective chemotherapeutic drug for osteosarcoma (37), resistance to the drug remains a major challenge. The current study therefore assessed the growth-inhibitory effects of cisplatin in MG63 cells via an MTT assay. MG63 cells were treated with different concentrations of cisplatin for 24 and $48 \mathrm{~h}$. It was determined that cell viability was negatively associated with cisplatin concentration (from $2.5-20 \mu \mathrm{g} / \mathrm{ml}$ ), with an $\mathrm{IC}_{50}$ value of $\sim 10 \mu \mathrm{g} / \mathrm{ml}$ at $48 \mathrm{~h}(\mathrm{P}<0.05$ and $\mathrm{P}<0.01 \mathrm{vs}$. normal group; Fig. 3A). A cisplatin concentration of $10 \mu \mathrm{g} / \mathrm{ml}$ was
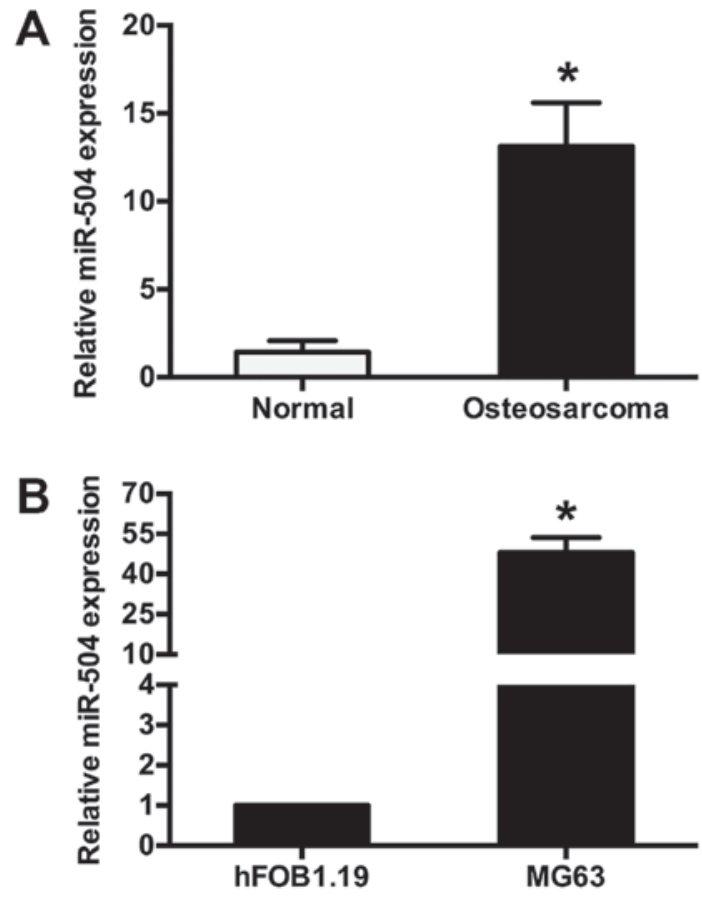

Figure 1. miR-504 expression is increased in osteosarcoma tissues and cells (A) miR-504 expression is osteosarcoma and normal tissues ( $\mathrm{n}=10$ pairs) as determined using RT-qPCR. (B) miR-504 levels in different cell types were also determined using RT-qPCR. Each, $n=3$. * $\mathrm{P}<0.05$ vs. normal and hFOB1.19 groups. miR, microRNA; RT-qPCR, reverse transcription quantitative polymerase chain reaction.

therefore selected for subsequent experiments. The effect of cisplatin on miR-504 expression in MG63 cells was assessed using RT-qPCR. Exposure of MG63 cells to $10 \mu \mathrm{g} / \mathrm{ml}$ cisplatin significantly suppressed miR-504 expression compared with the normal group $(\mathrm{P}<0.05$; Fig. 3B). These results indicated that cisplatin induced cell apoptosis and suppresses miR-504 expression in MG63 cells.

miR-504 suppresses cisplatin-induced cell apoptosis in MG63 cells. The role of miR-504 in cisplatin-induced MG63 cell apoptosis was assessed. Apoptosis rate was determined in each group treated with $10 \mu \mathrm{g} / \mathrm{ml}$ cisplatin for 24,48 or $72 \mathrm{~h}$. According to the MTT assay, miR-504 significantly decreased cisplatin-induced cell apoptosis compared with the normal group at all time points $(\mathrm{P}<0.05$; Fig. $3 \mathrm{C})$. No significant differences were identified between the normal and miR-NC groups. The morphological changes associated with MG63 cell cisplatin-induced apoptosis were assessed using phase contrast microscopy. Apoptotic rate (non-adherent cells) were significantly increased in the miR-NC+cisplatin group compared with the miR-NC group $(\mathrm{P}<0.05)$ and were significantly decreased in the miR-504+cisplatin group compared with the miR-NC+cisplatin group $(\mathrm{P}<0.05)$. There was no significant difference between the miR-NC and miR-504 groups (Fig. 3D). Similar trends were also observed via the Hoechst 33258 staining assay (Fig. 3E). The involvement of miR-504 in cisplatin-induced cell apoptosis was confirmed via flow cytometry, which revealed that cisplatin treatment significantly increased cell apoptosis in the miR-NC+cisplatin group compared with the miR-NC group $(\mathrm{P}<0.05$; Fig. $4 \mathrm{~A})$, the same result was also 

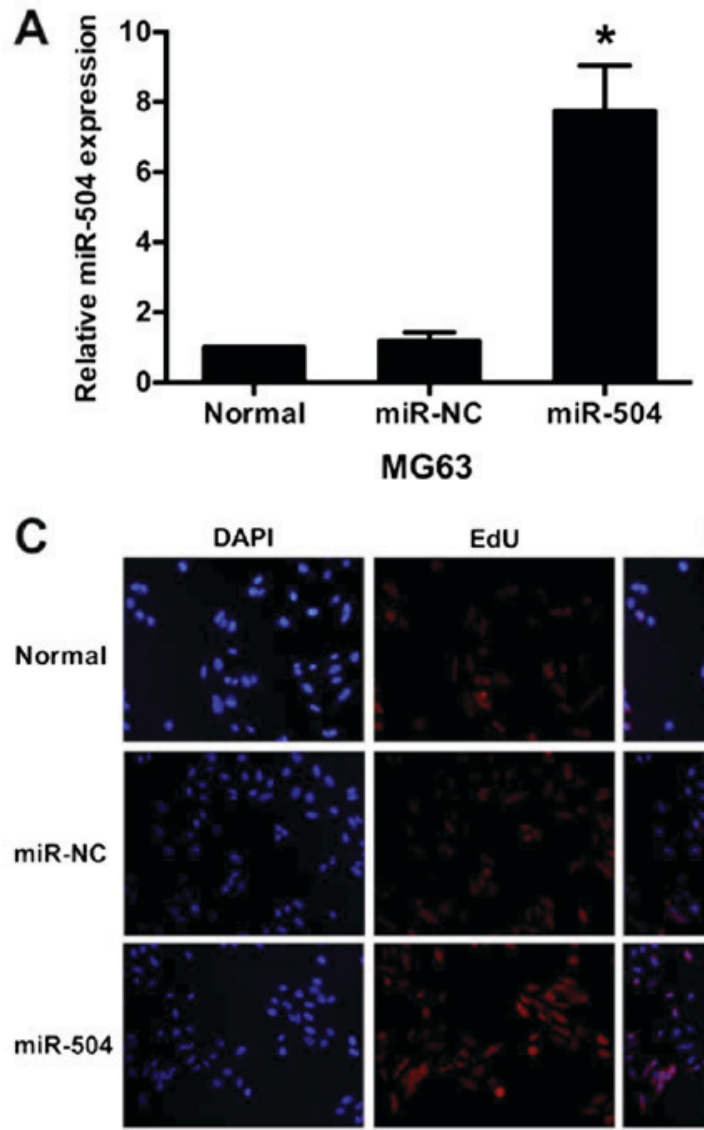

B

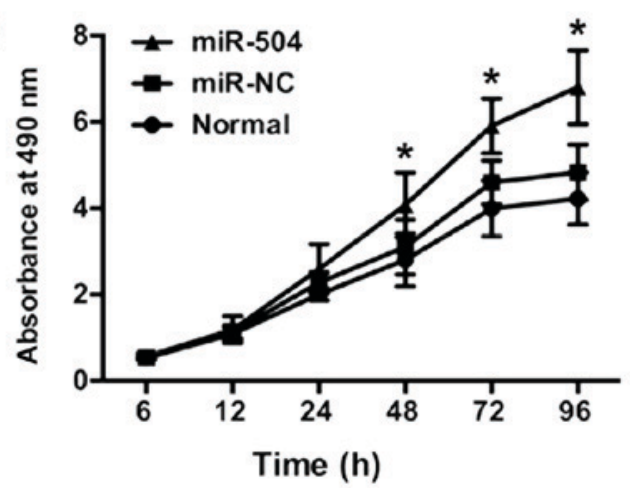

Figure 2. Transfection with n miR-504 lentivirus promoted MG63 cell proliferation. (A) miR-504 expression was determined in each group using a reverse transcription-quantitative polymerase chain reaction assay. (B) miR-504 overexpression significantly promoted MG63 cell proliferation (miR-504 group, from $48 \mathrm{~h}$ ), as determined via an MTT assay. (C) MG63 cell proliferation was significantly increased in the miR-504 group as determined by an EdU-incorporation assay under inverted phase contrast microscopy (magnification, $\mathrm{x} 400$ ). Each, $\mathrm{n}=3 .{ }^{*} \mathrm{P}<0.05$ vs. normal group. miR, microRNA; NC, normal control.

A

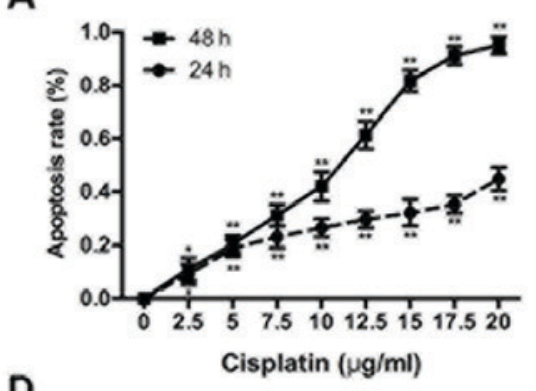

B

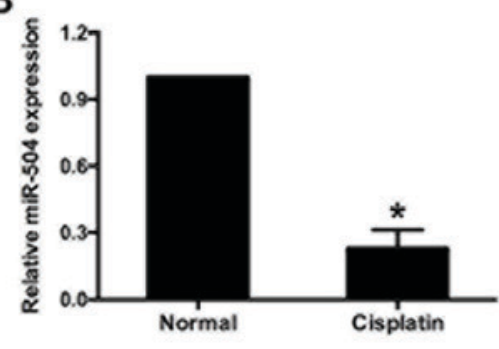

E
C

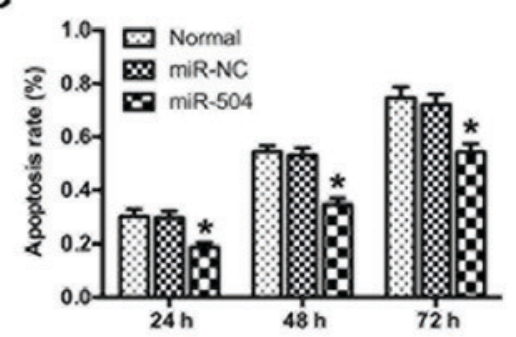

Cisplatin treatment times

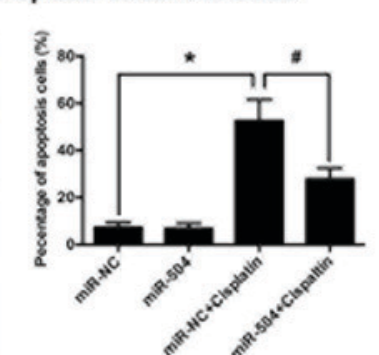

Figure 3. Cisplatin promoted MG63 cell apoptosis by decreasing miR-504. (A) MG63 cells were exposed to different concentrations $(0,2.5,5,7.5,10$, $12.5,15,17.5$ and $20 \mu \mathrm{l}$ ) of cisplatin for 24 or $48 \mathrm{~h}$ and an MTT assay was performed to determine apoptosis rate. At a concentration of $10 \mu \mathrm{g} / \mathrm{ml} \sim 50 \%$ of cells died following $48 \mathrm{~h} .{ }^{*} \mathrm{P}<0.05$ and ${ }^{* *} \mathrm{P}<0.01$ vs. the untreated MG63 cells, at 24 and $48 \mathrm{~h}$, respectively. (B) Cisplatin treatment significantly suppressed miR-504 expression in MG63 cells, as determined using a reverse transcription-quantitative polymerase chain reaction assay. ${ }^{*} \mathrm{P}<0.05$ vs. the normal group. (C) MG63 cells were exposed to $10 \mu \mathrm{g} / \mathrm{ml}$ cisplatin for 24,48 or $72 \mathrm{~h}$ and an MTT assay was performed to assess apoptosis rate. "P< $<0.05$ vs. the normal group. (D) The morphological appearance of MG63 cells exposed to $10 \mu \mathrm{g} / \mathrm{ml}$ cisplatin for $48 \mathrm{~h}$ was observed under an inverted phase-contrast microscope (magnification, $\mathrm{x} 100)$. ${ }^{*} \mathrm{P}<0.05$ vs. the miR-NC group; ${ }^{\prime} \mathrm{P}<0.05$ vs. the miR-NC+cisplatin group. (E) The nuclear morphology of MG63 cells exposed to $10 \mu \mathrm{g} / \mathrm{ml}$ cisplatin for $48 \mathrm{~h}$ was observed by Hoechst 33258 staining and inverted phase contrast microscopy (magnification, $\mathrm{x} 400$ ). Each, $\mathrm{n}=3$; ${ }^{*} \mathrm{P}<0.05 \mathrm{vs}$. the miR-NC group; ${ }^{*} \mathrm{P}<0.05$ vs. the miR-NC+cisplatin group. miR, micro RNA; NC, negative control. 

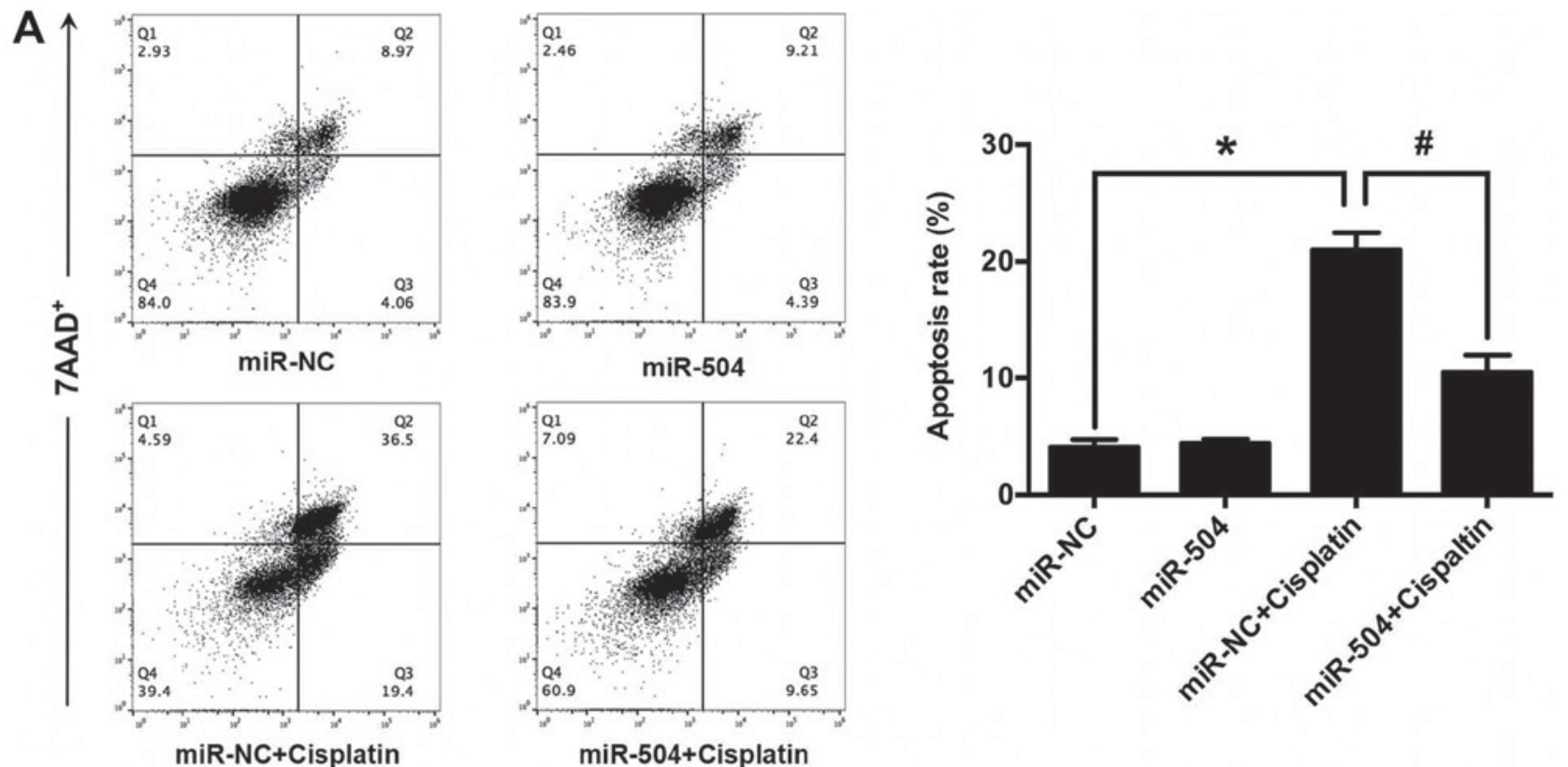

Annexin V-APC+

B
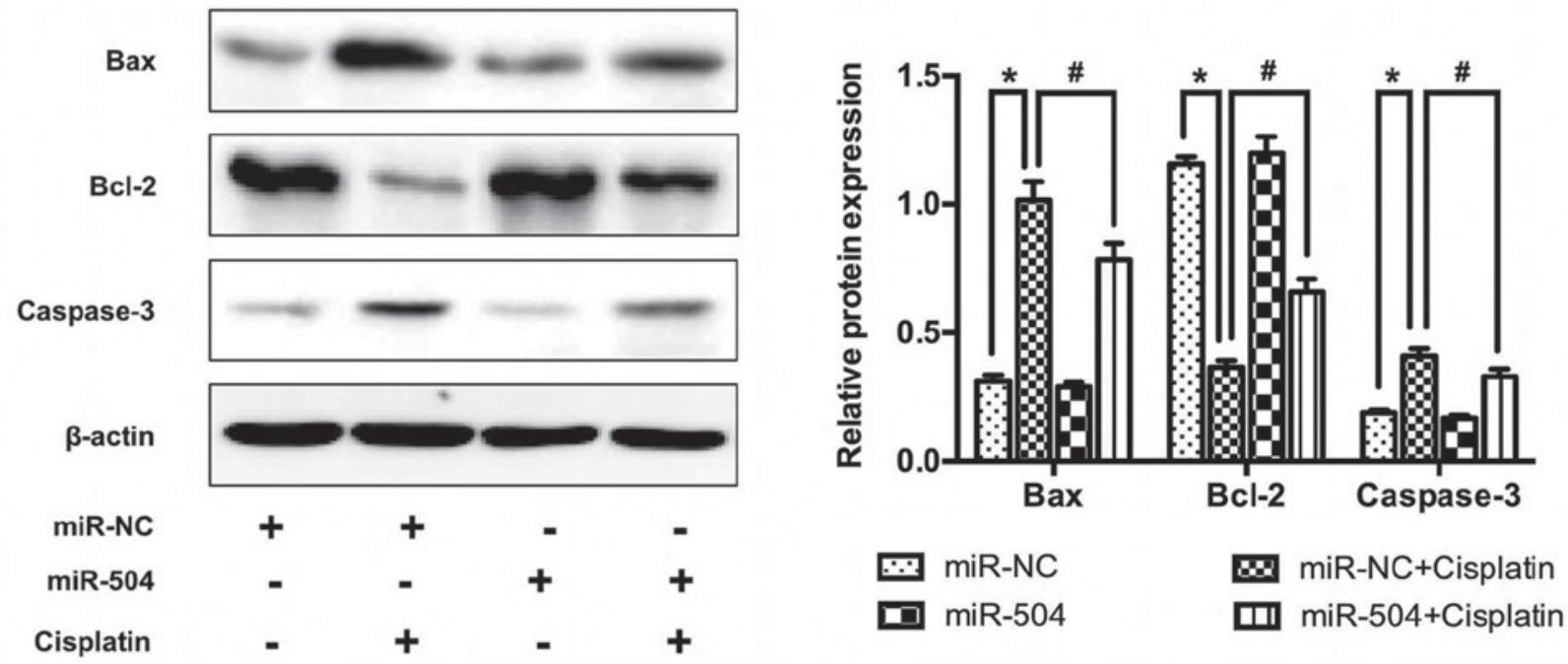

Figure 4. miR-504 decreased cisplatin-mediated MG63 cell apoptosis. (A) MG63 cell apoptosis was stained with Annexin V-APC/7AAD and detected using flow cytometry following treatment with $10 \mu \mathrm{g} / \mathrm{ml}$ cisplatin for $48 \mathrm{~h}$. ${ }^{*} \mathrm{P}<0.05$ vs. the miR-NC group; ${ }^{*} \mathrm{P}<0.05 \mathrm{vs}$. the miR-NC+cisplatin group. (B) Apoptosis-associated protein expression in MG63 cells was assessed via western blotting, with $\beta$-actin as an internal reference. Each, $\mathrm{n}=3$. * $\mathrm{P}<0.05$ vs. the miR-NC group. ${ }^{\#} \mathrm{P}<0.05$ vs. the miR-NC+cisplatin group. miR, microRNA; NC, negative control; bax, Bcl-2-associated protein X; Bcl-2, B-cell lymphoma 2.

revealed between miR-504 group and miR-504+cisplatin group. Furthermore, miR-504 significantly decreased cell apoptosis in the miR-504+cisplatin group compared with the miR-NC+cisplatin group $(\mathrm{P}<0.05)$. No significant differences were identified between the miR-NC and miR-504 groups. To further assess the molecular mechanisms of miR-504, western blotting was performed. The results demonstrated that cisplatin treatment significantly increased Bax and caspase-3 (pro-apoptotic protein) expression in the miR-NC+cisplatin group compared with the miR-NC group $(\mathrm{P}<0.05)$. Furthermore, miR-504 significantly decreased the expression of Bax and caspase-3 in the miR-504+cisplatin group compared with the miR-NC+cisplatin group $(\mathrm{P}<0.05)$. No significant differences were identified between the miR-NC and miR-504 groups. The anti-apoptotic protein
Bcl-2 demonstrated the opposite trends not only in the miR-NC+cisplatin group compared with the miR-NC group $(\mathrm{P}<0.05)$, but also in the miR-504+cisplatin group compared with the miR-NC+cisplatin group $(\mathrm{P}<0.05$; Fig. $4 \mathrm{~B})$. These results demonstrated that miR-504 suppressed cisplatin-induced MG63 cell apoptosis.

miR-504 suppresses cisplatin-induced cell cycle arrest in MG63 cells. The involvement of miR-504 in cisplatin-induced MG63 cell cycle arrest was determined using flow cytometry. Cisplatin treatment significantly increased the percentage of $\mathrm{G}_{0} / \mathrm{G}_{1}$ phase cells in the miR-NC+cisplatin group compared with the miR-NC group ( $\mathrm{P}<0.05$; Fig. $5 \mathrm{~A})$. However, miR-504 significantly decreased the percentage of cells in $G_{0} / G_{1}$ phase in the miR-504+cisplatin group 
A

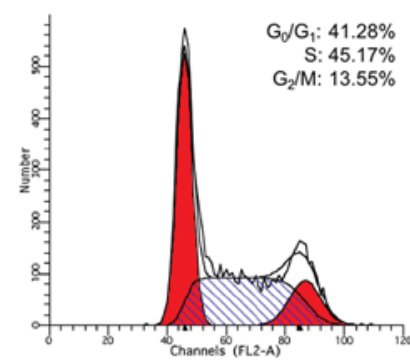

miR-NC

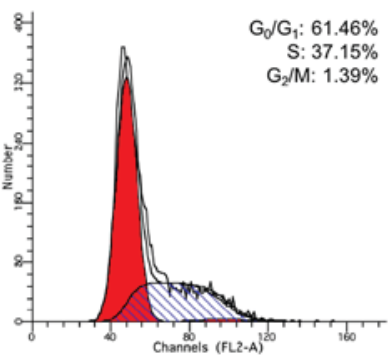

miR-NC+Cisplatin

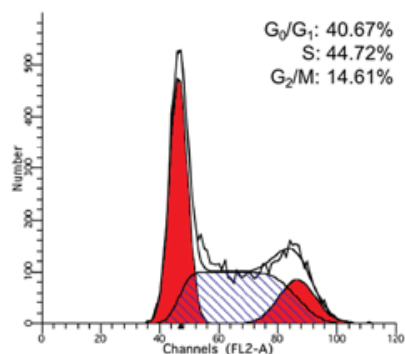

miR-504

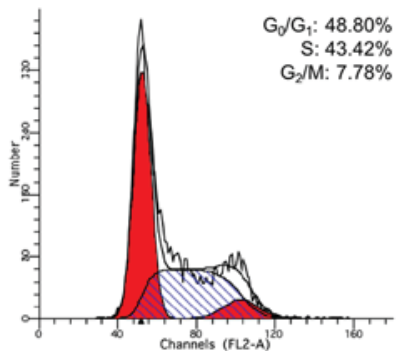

miR-504+Cisplatin

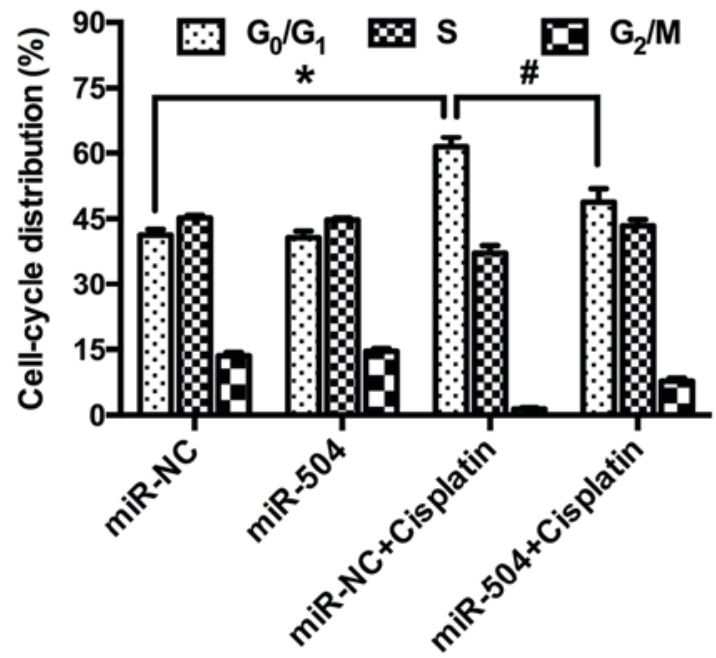

B

p21

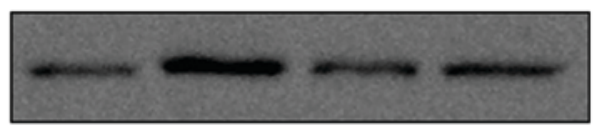

Cyclin D1

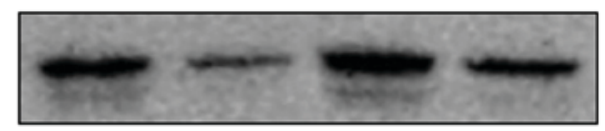

$\beta$-actin

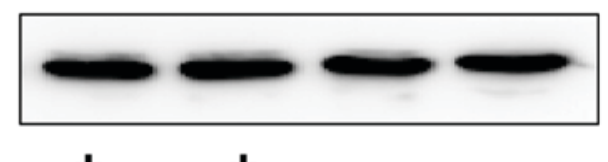

miR-NC

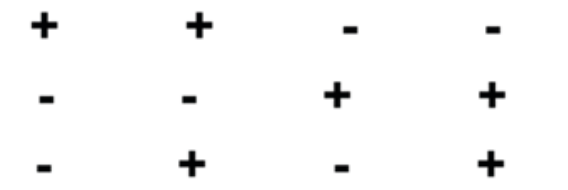

miR-504

Cisplatin

Figure 5. miR-504 suppressed cisplatin-induced cell cycle arrest in MG63 cells. (A) MG63 cells were treated with cisplatin (10 $\mu \mathrm{g} / \mathrm{ml})$ for $24 \mathrm{~h}$ and the cell cycle distribution was analyzed using flow cytometry. ${ }^{*} \mathrm{P}<0.05$ vs. the miR-NC group; ${ }^{*} \mathrm{P}<0.05$ vs. the miR-NC+cisplatin group. (B) Cell cycle-associated protein expression in MG63 cells was detected via western blot analysis, with $\beta$-actin as an internal reference. ${ }^{*} \mathrm{P}<0.05$ vs. the miR-NC group; ${ }^{\sharp} \mathrm{P}<0.05$ vs. the miR-NC+cisplatin group. Each, $\mathrm{n}=3$. miR, microRNA; NC, negative control.

compared with the miR-NC+cisplatin group $(\mathrm{P}<0.05)$. No significant differences were identified between the miR-NC and miR-504 groups. The underlying molecular mechanism was assessed using western blotting, which revealed that cisplatin significantly increased the expression of p21 (a non-specific suppressor of cell cycle progression) in the miR-NC+cisplatin group compared with the miR-NC group $(\mathrm{P}<0.05)$. Additionally, miR-504 treatment significantly decreased the expression of $\mathrm{p} 21$ in the miR-504+cisplatin group compared with the miR-NC+cisplatin group $(\mathrm{P}<0.05)$. There were no significant differences between the miR-NC and the miR-504 groups. Additionally, cisplatin treatment significantly decreased the expression of cyclin D1 (a specific promotor of $\mathrm{G}_{1}$ to $\mathrm{S}$ phase) in the miR-NC+cisplatin group compared with the miR-NC group $(\mathrm{P}<0.05)$. Additionally, it was determined that miR-504 significantly increased cyclin D1 expression in the miR-504+cisplatin group compared with the miR-NC+cisplatin group $(\mathrm{P}<0.05$; Fig. $5 \mathrm{~B})$.
However, no significant differences were identified between the miR-NC and miR-504 groups. These results indicate that miR-504 suppressed cisplatin-induced $\mathrm{G}_{0} / \mathrm{G}_{1}$ arrest in MG63 cells.

p53 is a direct target of miR-504 in MG63 cells. p53-mediated apoptosis is a primary mechanism by which p53 effects tumor suppression (38). Hu et al (20) demonstrated that miR-504 negatively regulates the expression of p53 in various types of cell by binding to the 3'-UTR of p53 mRNA. The current study therefore hypothesized that p53 may be a target gene of miR-504 in osteosarcoma cells. The TargetScanHuman database (Release 7.1, http://www.targetScan.org) identified a putative region (at position 200-206) in the 3'-UTR of p53 mRNA that may bind to miR-504 (Fig. 6A). Whether miR-504 directly targeted p53 was then assessed using a luciferase reporter assay. The results demonstrated that luciferase activity was significantly decreased in wt miR-504 
A Position $200-206$ of p53 3'-UTR

hsa-miR-504

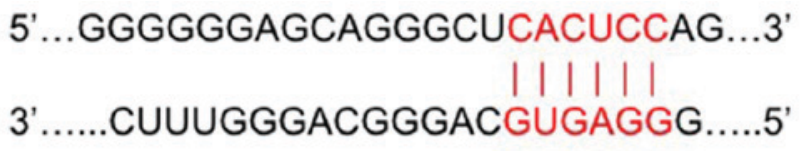

B

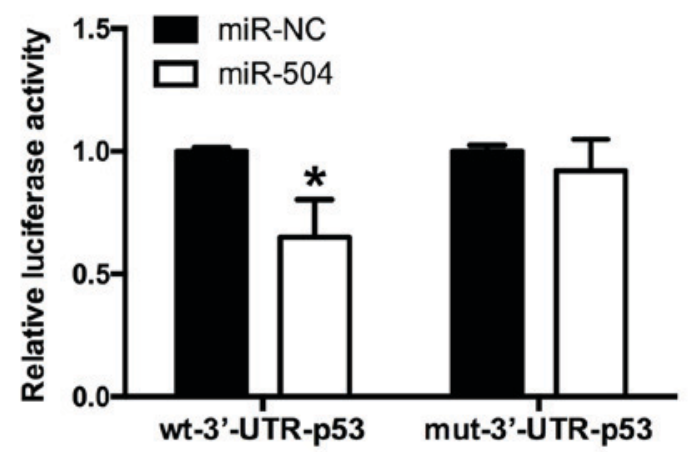

Luciferase
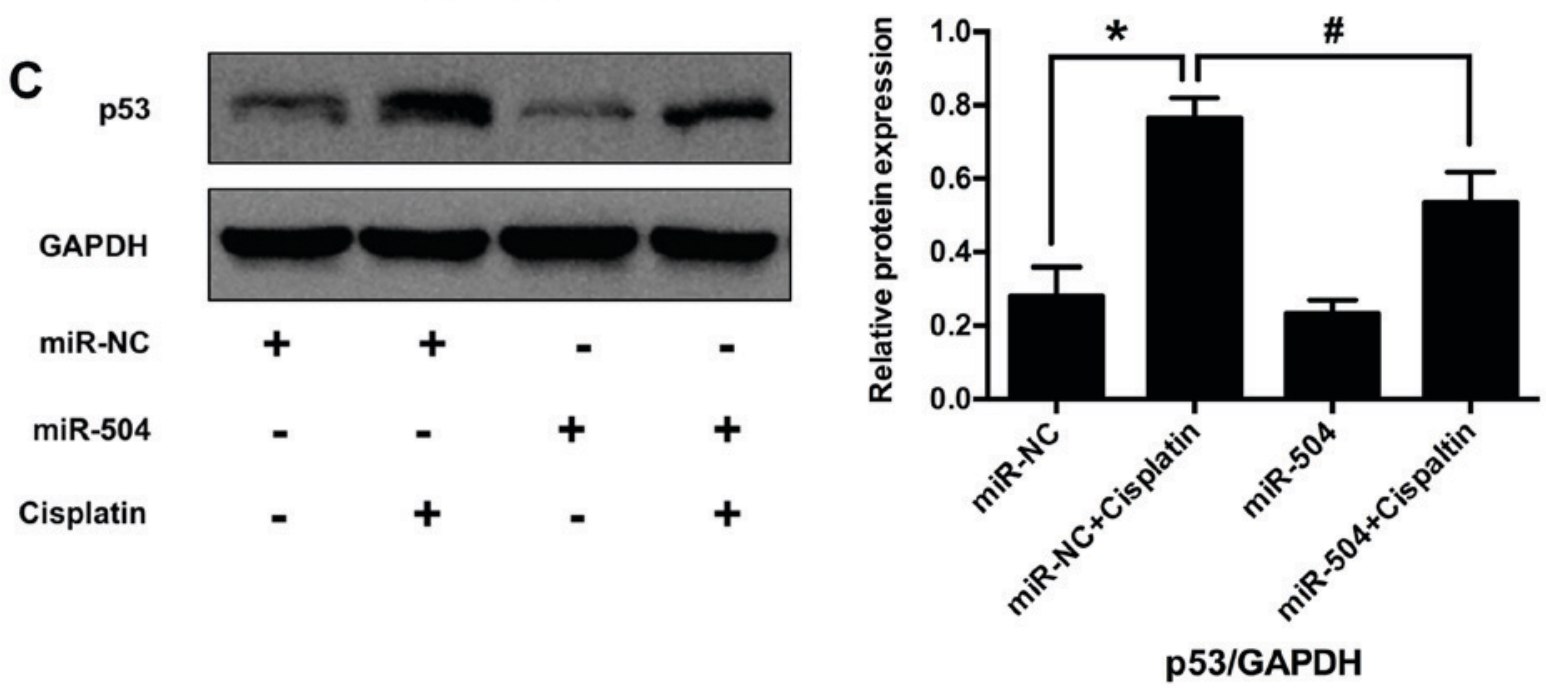

Figure 6. miR-504 negatively regulated p53 expression in MG63 cells. (A) miR-504 was predicted to bind to the 3'-UTR of p53 mRNA, according to TargetScanHuman Release 7.1 software (http://www.targetscan.org). (B) A luciferase assay was used to assess whether miR-504 directly targeted p53 in 293 cells co-transfected with wt-3'-UTR-p53 or mut-3'-UTR-p53 reporter plasmids and either miR-504 or miR-NC. * $\mathrm{P}<0.05$ vs. the miR-NC group. (C) p53 expression was assessed via western blotting following miR-504 overexpression and cisplatin treatment in MG63 cells. GAPDH was used as an internal reference. " $\mathrm{P}<0.05$ vs. the miR-NC group; ${ }^{~} \mathrm{P}<0.05$ vs. the miR-NC+cisplatin group. Each, $\mathrm{n}=3$. miR, miRNA; UTR, untranslated region; wt, wild type; mut, mutant; NC, negative control.

compared with wt miR-NC $(\mathrm{P}<0.05$; Fig. 6B). No significant differences were identified between mut miR-504 and mut miR-NC groups. These results indicate that p53 is a direct target of miR-504 in MG63 cells.

p53 participates in miR-504-mediated cell apoptosis and cell cycle arrest in MG63 cells. The role of p53 in miR-504-reduced MG63 cell apoptosis was assessed via western blotting. The results demonstrated that cisplatin significantly increased p53 expression in the miR-NC+cisplatin group compared with the miR-NC group $(\mathrm{P}<0.05$; Fig. 6C). Furthermore, miR-504 significantly decreased the expression of p53 in the miR-504+cisplatin group compared with the miR-NC+cisplatin group $(\mathrm{P}<0.05)$. However, no significant differences were identified between the miR-NC and miR-504 groups. These results indicated that p53 may be involved in miR-504-mediated cell apoptosis and cell cycle arrest in MG63 cells.

\section{Discussion}

Osteosarcoma is the most common human primary malignant bone tumor that is primarily characterized by local pain and early metastasis (38). Although osteosarcoma may be treated via surgery and chemotherapy, its clinical prognosis remains poor. Osteosarcoma has been a recent focus of research at the molecular level and studies have indicated that miRNAs serve important roles in the development of osteosarcoma $(39,40)$. Several miRNAs have exhibited abnormal expressions in osteosarcoma occurrence. For example, miR-93, miR-181a and miR-191 are identified to be upregulated and miR-34a, miR-145 and miR-199a-3p are downregulated (41). The current study revealed that miR-504 promoted proliferation and suppressed apoptosis, indicating that it may serve an oncogenic role in osteosarcoma.

Cisplatin is the most commonly used anti-osteosarcoma drug due to its unique therapeutic advantages, which include a high 
efficiency, mild side effects and easy administration. However, cisplatin resistance is frequently reported, meaning that the enhancement of cisplatin sensitivity is important for chemotherapy (42). Song et al (43) demonstrated that lysophosphatidic acid acytltransferase $\beta$ silencing decreased cisplatin resistance in osteosarcoma cells by activating the phosphoinositide 3-kinase/protein kinase $\mathrm{B} /$ mammalian target of rapamycin signaling pathway. Furthermore, Kim et al (44) revealed that GDNF receptor alpha 1 could overcome cisplatin resistance in osteosarcoma by inhibiting AMP-activated protein activated kinase-dependent autophagy. Additionally, Zheng et al (45) demonstrated that MAX dimerization protein 1-mediated hypoxia-induced cisplatin resistance in osteosarcoma cells by suppressing the expression of phosphatase and tensin homolog. miRs have also been identified as novel modulators that regulate the effect of cisplatin in osteosarcoma. For example, miR-133b, miR-21 and miR-214 were revealed to be involved in the induction of cisplatin resistance in osteosarcoma cells (46-48), whilst miR-125b, miR-138 and miR-199a-5p enhanced osteosarcoma cell cisplatin sensitivity (49-51).

However, previous studies have revealed that miR-504 expression differs among different types of human tumor cell; miR-504 expression was increased in oral squamous carcinoma (52), pancreatic ductal adenocarcinoma (53) and gastric cancer cells (54). Furthermore, miR-504 overexpression was demonstrated to promote tumor proliferation and reduce tumor sensitivity to radiotherapy and chemotherapy. However, miR-504 expression was decreased in hypopharyngeal squamous cell carcinoma (55) and glioma (56). The present study demonstrated that miR-504 was overexpressed in osteosarcoma tissues and MG63 cells, which lead to the hypothesis that it may be involved in osteosarcoma occurrence and progression. The lentivirus-mediated expression of miR-504 in MG63 cells indicated that miR-504 promoted cell proliferation and reduced the cisplatin sensitivity by suppressing MG63 cell apoptosis. This suggests that miR-504 may be a sensitive index for the evaluation of cisplatin's therapeutic effect. However, further studies are required to clarify the mechanisms involved in this process.

The tumor suppressor protein, p53, activates DNA repair proteins following DNA damage and initiates apoptosis in cells with irreparable DNA damage to avoid the division of abnormal genetic information (57). The p53 protein distinguishes DNA damage by inducing cell cycle arrest on $\mathrm{G}_{1} / \mathrm{S}$ phase (58). DNA damage induces the phosphorylation of $\mathrm{p} 53$, allowing it to dissociate from E3 ubiquitin-protein ligase mdm 2 and cause p53-mediated tumor suppression via cell cycle arrest or apoptosis (59). The p53 gene is mutated in $>50 \%$ of all types of malignant tumor and its mutations have been demonstrated to be involved in osteosarcoma tumorigenesis (60). Furthermore, Li-Fraumeni syndrome is a hereditary condition caused by the lack of the tumor suppressor p53 gene, which leads to the development and progression of multiple types of malignant tumor, including osteosarcoma (61). The current study demonstrated that miR-504 suppresses cell apoptosis and reduced $G_{1}$ arrest by negatively regulating p53, implying that miR-504 serves as an oncogene in osteosarcoma.

Potential miRNA targets can be predicted using bioinformatics software, including TargetScan. However, miRNAs possess cell-specific target genes and functions, meaning these predictions need to be confirmed experimentally. It has been revealed that miR-504 mediates the expression of p53 in mammary tumors (62) and in gastric carcinoma (63). The current study therefore hypothesized that p53 may also be a target gene of miR-504 in osteosarcoma, which was confirmed by the results obtained. Furthermore, previous studies have reported that miR-34a (64), miR-125b (65), miR-192 and miR-215 (66) negatively regulate p53 function, particularly p53-mediated cell apoptosis and cell cycle arrest. However, to the best of our knowledge, the current study provides the first evidence to verify that miR-504 promotes cell proliferation and suppresses the apoptosis of osteosarcoma cells by targeting p53. The present study further assessed the changes in apoptosis- and cell cycle-associated proteins at a molecular level. The results revealed that miR-504 overexpression suppresses apoptosis and induces the $\mathrm{G}_{1}$ arrest of MG63 cells by regulating these proteins. However, further studies assessing the in vitro knockdown of miR-504 are required to confirm the results of the current study. Furthermore, subsequent studies performed by the present authors will include in vivo studies that assess patient clinicopathological characteristics, which will further validate these results.

In conclusion, the current study revealed that miR-504 promotes proliferation and suppresses cisplatin-induced osteosarcoma cell apoptosis by targeting p53. However, further studies are required to clarify the association between miR-504 and p53, and the molecular mechanisms that are involved. The present results indicate that miR-504 may be an effective marker for the prediction of osteosarcoma occurrence and progression, and its sensitivity to cisplatin chemotherapy.

\section{Acknowledgements}

The authors would like to thank Dr. Junying Sun for his review of the manuscript and the Faculty of the Translational Medicine Laboratory of the First Affiliated Hospital of Wenzhou Medical University for supplying the laboratory to finish this study.

\section{Funding}

No funding was received.

\section{Availability of data and materials}

All data generated or analyzed during this study are included in this published article.

\section{Authors' contributions}

JS designed the study to predict microRNA-504's role in modulating osteosarcoma cell chemoresistance to cisplatin. $\mathrm{CL}, \mathrm{ZH}$ and SY analyzed and interpreted the patient data regarding osteosarcoma. XC, XZ and WL performed the histological collection of human osteosarcoma tissues and adjacent normal tissues. CL and LW performed the in vitro study, which including MTT, cell apoptosis assay, cell cycle analysis, dual luciferase reporter assay and western blot analysis. XC, CL and JS were major contributors in writing the manuscript. All authors read and approved the final manuscript. 


\section{Ethics approval and consent to participate}

All procedures performed in studies involving human participants were in accordance with the ethical standards of the institutional and/or national research committee and with the 1964 Helsinki declaration and its later amendments or comparable ethical standards. The present study was approved by the Clinical Ethics Committee of the First Affiliated Hospital of Wenzhou Medical University. All participants provided written informed consent and supported the study.

\section{Patient consent for publication}

Patients provided consent for the publication of the present study and respective associated publications.

\section{Competing interests}

The authors declare that they have no competing interests.

\section{References}

1. Endo-Munoz L, Evdokiou A and Saunders NA: The role of osteoclasts and tumour-associated macrophages in osteosarcoma metastasis. Biochim Biophys Acta 1826: 434-442, 2012.

2. Poletajew S, Fus L and Wasiutynski A: Current concepts on pathogenesis and biology of metastatic osteosarcoma tumors. Ortop Traumatol Rehabil 13: 537-545, 2011 (In English, Polish).

3. Lewis VO: What's new in musculoskeletal oncology. J Bone Joint Surg Am 91: 1546-1556, 2009.

4. Cho Y, Jung GH, Chung SH, Kim JY, Choi Y and Kim JD: Long-term survivals of stage IIb osteosarcoma: A 20-year experience in a single institution. Clin Orthop Surg 3: 48-54, 2011.

5. Bölling T, Schüller P, Distelmaier B, Schuck A, Ernst I, Gosheger G, Winkelmann W, Dirksen U, Jürgens H, Kronholz HL, et al: Perioperative high-dose rate brachytherapy using a bendy applicator (flab): Treatment results of 74 patients. Anticancer Res 28: 3885-3890, 2008.

6. Faisham WI, Mat Saad AZ, Alsaigh LN, Nor Azman MZ, Kamarul Imran M, Biswal BM, Bhavaraju VM, Salzihan MS, Hasnan J, Ezane AM, et al: Prognostic factors and survival rate of osteosarcoma: A single-institution study. Asia Pac J Clin Oncol 13: e104-e110, 2017.

7. Bacci G, Bertoni F, Longhi A, Ferrari S, Forni C, Biagini R, Bacchini P, Donati D, Manfrini M, Bernini G, et al: Neoadjuvant chemotherapy for high-grade central osteosarcoma of the extremity. Histologic response to preoperative chemotherapy correlates with histologic subtype of the tumor. Cancer 97: 3068-3075, 2003.

8. Ferrari S and Serra M: An update on chemotherapy for osteosarcoma. Expert Opin Pharmacother 16: 2727-2736, 2015.

9. Isakoff MS, Bielack SS, Meltzer P and Gorlick R: Osteosarcoma: Current treatment and a collaborative pathway to success. J Clin Oncol 33: 3029-3035, 2015.

10. Shukla GC, Singh J and Barik S: MicroRNAs: Processing, maturation, target recognition and regulatory functions. Mol Cell Pharmacol 3: 83-92, 2011.

11. Farh KK, Grimson A, Jan C, Lewis BP, Johnston WK, Lim LP, Burge CB and Bartel DP: The widespread impact of mammalian MicroRNAs on mRNA repression and evolution. Science 310: 1817-1821, 2005 .

12. Pasquinelli AE, Hunter S and Bracht J: MicroRNAs: Adeveloping story. Curr Opin Genet Dev 15: 200-205, 2005.

13. Bartel DP: MicroRNAs: Genomics, biogenesis, mechanism, and function. Cell 116: 281-297, 2004.

14. Bartel DP: MicroRNAs: Target recognition and regulatory functions. Cell 136: 215-233, 2009.

15. Baer C, Claus R and Plass C: Genome-wide epigenetic regulation of miRNAs in cancer. Cancer Res 73: 473-477, 2013.

16. Lin S, Pan L, Guo S, Wu J, Jin L, Wang JC and Wang S: Prognostic role of microRNA-181a/b in hematological malignancies: A meta-analysis. PLoS One 8: e59532, 2013.
17. Meng Y, Gao R, Ma J, Zhao J, Xu E, Wang C and Zhou X: MicroRNA-140-5p regulates osteosarcoma chemoresistance by targeting HMGN5 and autophagy. Sci Rep 7: 416, 2017.

18. Vanas V, Haigl B, Stockhammer V and Sutterlüty-Fall H: MicroRNA-21 increases proliferation and cisplatin sensitivity of osteosarcoma-derived cells. PLoS One 11: e0161023, 2016.

19. Liu Y, Zhu ST, Wang X, Deng J, Li WH, Zhang P and Liu BS: MiR-200c regulates tumor growth and chemosensitivity to cisplatin in osteosarcoma by targeting AKT2. Sci Rep 7: 13598, 2017.

20. Hu W, Chan CS, Wu R, Zhang C, Sun Y, Song JS, Tang LH, Levine AJ and Feng Z: Negative regulation of tumor suppressor p53 by microRNA miR-504. Mol Cell 38: 689-699, 2010.

21. Bedi A and Mookerjee B: Biological significance and molecular mechanisms of p53-induced apoptosis. Apoptosis 3: 237-244, 1998.

22. Velletri T, Xie N, Wang Y, Huang Y, Yang Q, Chen X, Chen Q, Shou P, Gan Y, Cao G, et al: P53 functional abnormality in mesenchymal stem cells promotes osteosarcoma development. Cell Death Dis 7: e2015, 2016.

23. Xie C, Wu B, Chen B, Shi Q, Guo J, Fan Z and Huang Y: Histone deacetylase inhibitor sodium butyrate suppresses proliferation and promotes apoptosis in osteosarcoma cells by regulation of the MDM2-p53 signaling. Onco Targets Ther 9: 4005-4013, 2016.

24. Zhao YX, Wang YS, Cai QQ, Wang JQ and Yao WT: Up-regulation of HDAC9 promotes cell proliferation through suppressing p53 transcription in osteosarcoma. Int J Clin Exp Med 8: 11818-11823, 2015.

25. Wu J, Guo A, Li Q and Wang D: Meta-analysis of clinical significance of p53 protein expression in patients with osteosarcoma. Future Oncol 13: 1883-1891, 2017.

26. van der Deen M, Taipaleenmäki H, Zhang Y, Teplyuk NM, Gupta A, Cinghu S, Shogren K, Maran A, Yaszemski MJ, Ling L, et al: MicroRNA-34c inversely couples the biological functions of the runt-related transcription factor RUNX2 and the tumor suppressor p53 in osteosarcoma. J Biol Chem 288: 21307-21319, 2013

27. Jiang J, Ma B, Li X, Jin W, Han C, Wang L and Wang H: MiR-1281, a p53-responsive MicroRNA, impairs the survival of human osteosarcoma cells upon ER stress via targeting USP39. Am J Cancer Res 8: 1764-1774, 2018.

28. He C, Xiong J, Xu X, Lu W, Liu L, Xiao D and Wang D: Functional elucidation of MiR-34 in osteosarcoma cells and primary tumor samples. Biochem Biophys Res Commun 388: 35-40, 2009.

29. Zhang W, Qian JX, Yi HL, Yang ZD, Wang CF, Chen JY, Wei XZ, Fu Q and Ma H: The microRNA-29 plays a central role in osteosarcoma pathogenesis and progression. Mol Biol (Mosk) 46: 622-627, 2012.

30. Cai Q, Zeng S, Dai X, Wu J and Ma W: miR-504 promotes tumour hrowth and metastasis in human osteosarcoma by targeting TP53INP1. Oncol Rep 38: 2993-3000, 2017.

31. Lv C, Hao Y and Tu G: MicroRNA-21 promotes proliferation, invasion and suppresses apoptosis in human osteosarcoma line MG63 through PTEN/Akt pathway. Tumour Biol 37: 9333-9342, 2016.

32. Cui R, Guan Y, Sun C, Bao Y, Chen L, Li G, Qiu B, Meng X, Pang C and Wang Y: A tumor-suppressive microRNA, miR-504, inhibits cell proliferation and promotes apoptosis by targeting FOXP1 in human Glioma. Cancer Lett 374: 1-11, 2016.

33. Livak KJ and Schmittgen TD: Analysis of relative gene expression data using real-time quantitative PCR and the 2(-Delta Delta C(T)) method. Methods 25: 402-408, 2001.

34. Agarwal V, Bell GW, Nam JW and Bartel DP: Predicting effective microRNA target sites in mammalian mRNAs. Elife: 4, 2015. doi: 10.7554/eLife.05005.

35. Stepanenko AA and Dmitrenko VV: HEK293 in cell biology and cancer research: Phenotype, karyotype, tumorigenicity, and stress-induced genome-phenotype evolution. Gene 569: 182-190, 2015.

36. Nieuwenhuijsen BW, Huang Y, Wang Y, Ramirez F, Kalgaonkar G and Young KH: A dual luciferase multiplexed high-throughput screening platform for protein-protein interactions. J Biomol Screen 8: 676-684, 2003.

37. Rosen G, Caparros B, Huvos AG, Kosloff C, Nirenberg A, Cacavio A, Marcove RC, Lane JM, Mehta B and Urban C: Preoperative chemotherapy for osteogenic sarcoma: Selection of postoperative adjuvant chemotherapy based on the response of the primary tumor to preoperative chemotherapy. Cancer 49: 1221-1230, 1982 . 
38. Bennett JH, Thomas G, Evans AW and Speight PM: Osteosarcoma of the jaws: A 30-year retrospective review. Oral Surg Oral Med Oral Pathol Oral Radiol Endod 90: 323-332, 2000.

39. Chang L, Shrestha S, LaChaud G, Scott MA and James AW: Review of microRNA in osteosarcoma and chondrosarcoma. Med Oncol 32: 613, 2015.

40. Ram Kumar RM, Boro A and Fuchs B: Involvement and clinical aspects of MicroRNA in osteosarcoma. Int J Mol Sci 17: pii: E877, 2016.

41. Kobayashi E, Hornicek FJ and Duan Z: MicroRNA involvement in osteosarcoma. Sarcoma 2012: 359739, 2012

42. Yang J, Guo W, Wang L, Yu L, Mei H, Fang S, Ji P, Liu Y, Liu G and Song Q: Cisplatin-resistant osteosarcoma cells possess cancer stem cell properties in a mouse model. Oncol Lett 12: 2599-2605, 2016.

43. Song L, Duan P, Gan Y, Li P, Zhao C, Xu J, Zhang Z and Zhou Q: Silencing LPAAT $\beta$ inhibits tumor growth of cisplatin-resistant human osteosarcoma in vivo and in vitro. Int J Oncol 50: 535-544, 2017.

44. Kim M, Jung JY, Choi S, Lee H, Morales LD, Koh JT, Kim SH, Choi YD, Choi C, Slaga TJ, et al: GFRA1 promotes cisplatin-induced chemoresistance in osteosarcoma by inducing autophagy. Autophagy 13: 149-168, 2017.

45. Zheng D, Wu W, Dong N, Jiang X, Xu J, Zhan X, Zhang Z and $\mathrm{Hu} Z$ : Mxd1 mediates hypoxia-induced cisplatin resistance in osteosarcoma cells by repression of the PTEN tumor suppressor gene. Mol Carcinog 56: 2234-2244, 2017.

46. Zou Y, Yang J, Wu J, Luo C and Huang Y: miR-133b induces chemoresistance of osteosarcoma cells to cisplatin treatment by promoting cell death, migration and invasion. Oncol Lett 15: $1097-1102,2018$

47. Ziyan W and Yang L: MicroRNA-21 regulates the sensitivity to cisplatin in a human osteosarcoma cell line. Ir J Med Sci 185 85-91, 2016.

48. Song YD, Li DD, Guan Y, Wang YL and Zheng J: miR-214 modulates cisplatin sensitivity of osteosarcoma cells through regulation of anaerobic glycolysis. Cell Mol Biol (Noisy-le-grand) 63: 75-79, 2017.

49. Zhu Z, Tang J, Wang J, Duan G, Zhou L and Zhou X: MiR-138 acts as a tumor suppressor by targeting EZH2 and enhances cisplatin-induced apoptosis in osteosarcoma cells. PLoS One 11: e0150026, 2016.

50. Wang F, Yu D, Liu Z, Wang R, Xu Y, Cui H and Zhao T: MiR-125b functions as a tumor suppressor and enhances chemosensitivity to cisplatin in osteosarcoma. Technol Cancer Res Treat 15: NP105-NP112, 2016.

51. Li Y, Jiang W, Hu Y, Da Z, Zeng C, Tu M, Deng Z and Xiao W: MicroRNA-199a-5p inhibits cisplatin-induced drug resistance via inhibition of autophagy in osteosarcoma cells. Oncol Lett 12: 4203-4208, 2016.

52. Yang $\mathrm{MH}$, Lin BR, Chang $\mathrm{CH}$, Chen ST, Lin SK, Kuo MY, Jeng YM, Kuo ML and Chang CC: Connective tissue growth factor modulates oral squamous cell carcinoma invasion by activating a miR-504/FOXP1 signalling. Oncogene 31: 2401-2411, 2012 .

53. Jiang $\mathrm{B}, \mathrm{Gu} \mathrm{Y}$ and $\mathrm{Chen} \mathrm{Y}$ : Identification of novel predictive markers for the prognosis of pancreatic ductal adenocarcinoma. Cancer Invest 32: 218-225, 2014
54. Soutto M, Chen Z, Saleh MA, Katsha A, Zhu S, Zaika A, Belkhiri $A$ and El-Rifai W: TFF1 activates p53 through down-regulation of miR-504 in gastric cancer. Oncotarget 5: 5663-5673, 2014

55. Kikkawa N, Kinoshita T, Nohata N, Hanazawa T, Yamamoto N, Fukumoto I, Chiyomaru T, Enokida H, Nakagawa M, Okamoto Y and Seki N: microRNA-504 inhibits cancer cell proliferation via targeting CDK6 in hypopharyngeal squamous cell carcinoma. Int J Oncol 44: 2085-2092, 2014

56. Guan Y, Chen L, Bao Y, Pang C, Cui R, Li G, Liu J and Wang Y: Downregulation of microRNA-504 is associated with poor prognosis in high-grade glioma. Int J Clin Exp Pathol 8: 727-734, 2015.

57. Mirzayans R, Andrais B, Kumar P and Murray D: Significance of wild-type p53 signaling in suppressing apoptosis in response to chemical genotoxic agents: Impact on chemotherapy outcome. Int J Mol Sci 18: pii: E928, 2017.

58. Vassilev LT, Vu BT, Graves B, Carvajal D, Podlaski F, Filipovic Z, Kong N, Kammlott U, Lukacs C, Klein C, et al: In vivo activation of the p53 pathway by small-molecule antagonists of MDM2. Science 303: 844-848, 2004.

59. Hu W, Feng Z, Ma L, Wagner J, Rice JJ, Stolovitzky G and Levine AJ: A single nucleotide polymorphism in the MDM2 gene disrupts the oscillation of p53 and MDM2 levels in cells. Cancer Res 67: 2757-2765, 2007.

60. Hansen MF: Molecular genetic considerations in osteosarcoma. Clin Orthop Relat Res: 237-246, 1991

61. Hauben EI, Arends J, Vandenbroucke JP, van Asperen CJ, Van Marck E and Hogendoorn PC: Multiple primary malignancies in osteosarcoma patients. Incidence and predictive value of osteosarcoma subtype for cancer syndromes related with osteosarcoma. Eur J Hum Genet 11: 611-618, 2003.

62. Ford NA, Dunlap SM, Wheatley KE and Hursting SD: Obesity, independent of p53 gene dosage, promotes mammary tumor progression and upregulates the p53 regulator microRNA-504. PLoS One 8: e68089, 2013

63. Fukuda Y, Kurihara N, Imoto I, Yasui K, Yoshida M, Yanagihara K, Park JG, Nakamura Y and Inazawa J: CD44 is a potential target of amplification within the 11p13 amplicon detected in gastric cancer cell lines. Genes Chromosomes Cancer 29: 315-324, 2000.

64. Novello C, Pazzaglia L, Conti A, Quattrini I, Pollino S, Perego P, Picci P and Benassi MS: p53-dependent activation of microRNA-34a in response to etoposide-induced DNA damage in osteosarcoma cell lines not impaired by dominant negative p53 expression. PLoS One 9: e114757, 2014.

65. Le MT, Teh C, Shyh-Chang N, Xie H, Zhou B, Korzh V, Lodish HF and Lim B: MicroRNA-125b is a novel negative regulator of p53. Genes Dev 23: 862-876, 2009.

66. Braun CJ, Zhang X, Savelyeva I, Wolff S, Moll UM, Schepeler T, Ørntoft TF, Andersen CL and Dobbelstein M: p53-responsive micrornas 192 and 215 are capable of inducing cell cycle arrest. Cancer Res 68: 10094-10104, 2008.

This work is licensed under a Creative Commons Attribution-NonCommercial-NoDerivatives 4.0 International (CC BY-NC-ND 4.0) License. 